\title{
混合体理論に基づく冠循環数理モデルの定式化*
}

$$
\begin{aligned}
& \text { 陳献*1, 杉 浦 清了*2 } \\
& \text { 砂川賢二*3, 久田俊 明*4 }
\end{aligned}
$$

\section{Formulation of the Theoretical Model of Coronary Circulation Based on Mixture Theory}

\author{
Xian $\mathrm{CHEN}^{* 5}$, Seiryo SUGIURA, \\ Kenji SUNAGAWA and Toshiaki HISADA \\ ${ }^{* 5}$ Digital Medicine Initiative, Kyushu University, \\ 3-1-1 Maidashi, Higashi-ku, Fukuoka-shi, Fukuoka, 812-8582 Japan
}

\begin{abstract}
The disorder of the coronary circulation system, which supplies blood for the working heart, may cause ischemic heart disease such as myocardial infarction, angina pectoris. On the other hand, the interaction between intramyocardial pressure and coronary blood flow is recognized to be an important factor that influences the hemodynamics of coronary circulation. In this work, a multiphasic model for coronary circulation system is proposed based on mixture theory by treating the myocardial matrix and the blood in hierarchical coronary system as solid phase and multi-fluid phase respectively. The governing equations and constitutive relations have been derived by applying conservation laws and entropy inequality in the framework of mixture theory. The microscopic properties, such as the viscosity of blood or the compliance of the micro vessel are represented by their macroscopic counterparts. The abilities of representing the characteristic behavior of coronary system have been confirmed by numerical examples.
\end{abstract}

Key Words: Biomechanics, Medical Engineering, Finite Element Method, Coronary Circulation, Mixture Theory

\section{1. 緒言}

心臟への血液供給を行う冠循環の障害は虚血性心疾 患と呼ばれる心筋梗塞, 狭心症などの重篤な症状をも たらすため, 冠循環メカニズムの解明は臨床医学上重 要な意義を持っている. ほかの臓器とは異なり, 冠循 環では心臟から血液を拍出する収縮期には冠動脈血流 は少なく, 動脈圧が低下寸る拡張期には多く流れる「拡 張期優位」，またそれとは逆に冠静脈では「収縮期優 位」が特徴として知られる. またそのメカニズムは心 筋内血液容量の変化や心筋圧に抵抗する血管弾性など に依存するが,特に心笳収縮による心筋圧に大きく影 響を受ける(1). 一方，冠循環血管系は図 1 に示すよう に樹状構造を持ち，心外膜側の太い血管は細い血管に 分岐しながら心室壁を穿通し心内膜側に到達し, 最終 的に冠血管系の末梢は図 2 に示すように細動脈と細静 脈として毛細血管床に埋め込まれる。このような樹状

\footnotetext{
* 原稿受付 2008 年 5 月 19 日.

*1 正員, 九州大学デジタルメディシン・イニシアティブ (画 812-8582 福岡市東区馬出 3-1-1).

*2 東京大学大学院新領域創成科学研究科 (E113-0033 東京都 文京区本郷 7-3-1).

*3 九州大学大学院医学研究院.

*4 正員, フェロー, 東京大学大学院新領域創成科学研究科.

E-mail : xchen@digital.med.kyushu-u.ac.jp
}

構造における各階層（compartment）の血管は異なる生 理学的機能（例えば, 細動脈の抵抗血管機能(2)など) と組織学的形態（径や湾曲, 分岐など）に基づく力学 的特徵（血液流れに対する抵抗など）を持ち，また， 微小動脈・毛細血管・微小静脈からなる微小循環系は 心筋への血液供給に重要な役割を果たしている. 従っ て，臨床応用を目指した冠循環モデル化においては、 上述の生理学的、力学的特徴, 即ち, 心筋圧, 各階層 血流に対する抵抗や血管弾性及ひ微小循環を表現でき ることが要求される.

従来, 冠動脈における「拡張期優位」及び収縮期に 心臓壁内層から外層に向かう逆流，また冠静脈におけ る「収縮期優位」などの現象に対して主に電気回路モ デルによる説明が試みられてきた. しかし，このよう な現象論的モデルではある程度の現象は説明可能であ るが，観察限界を超えたミクロ現象，特に毛細血管に よる心筋内血液容量調節機能を再現し分析することは 困難である. 一方，心筋内全ての血管をモデル化し 1 次元的な流れ解析によって冠循環における血行動態を 解析する試みもなされているが(3)，重要な毛細管レべ ルの再現は困難であり、また心筋収縮との連成も未だ 手が付けられていない. 


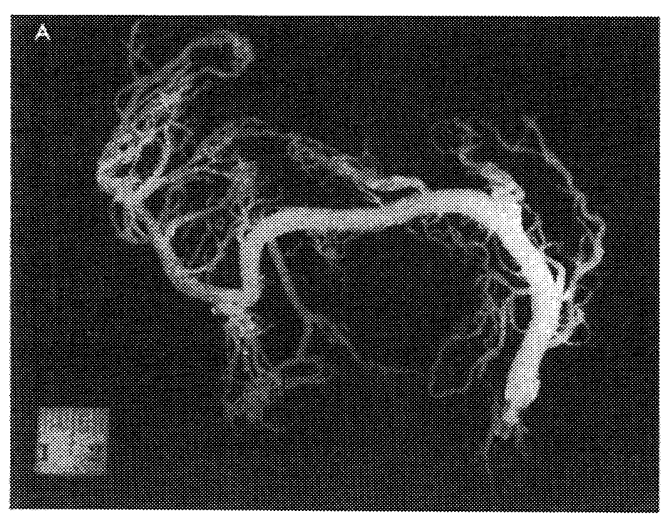

Fig. 1 Casts of pig right coronary artery (Reproduced from Kassab et al. ${ }^{(4)}$ with permission of American Physiological Society in the format Journal via Copyright Clearance Center)

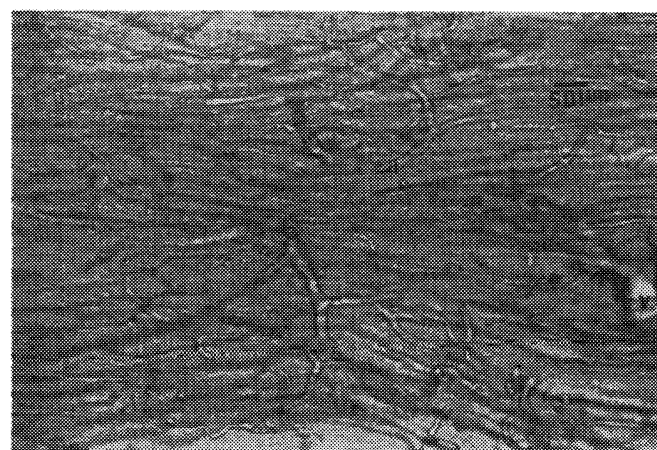

Fig. 2 Photomicrographs in pig left ventricle: 70 - $\mu \mathrm{m}$-thick section taken $\sim 3.9 \mathrm{~mm}$ from epicardial surface shows several neighboring arterioles (a) feeding a capillary bed and a nearby venule ( $v$ ) draining it (Reproduced from Kassab et al. (4) with permission of American Physiological Society in the format Journal via Copyright Clearance Center)

一方，一種のマルチスケール解析手法として，マク 口的対象物をミクロ的各成分からなる混合体とみなし， ミク口成分間の相互作用の平均的特性をマク口的挙動 に反映させる混合体理論(5)を生体シミュレーションに 導入するアプローチが提案されている(6). 混合体理論 に基づく冠循環モデル化に関する先行研究としては Huyghe らのグループが提案した一連の階層型混合体 モデルの開発が挙げられる(7-13).これらの先駆的研究で は, 動脈から毛細血管さらに静脈に至る冠循環系を連 続的階層構造として捉え, 階層を表す新たな次元変数 を導入した混合体モデル化を提案している.これによ り, 冠循環系における細動脈, 細静脈, 毛細血管など
の組織学的形態も生理学的機能も異なる血管系を各自 の階層変数に対応させ，それぞれに適した物理的特性 を導入することが可能となる. 本研究では Huyghe ら の研究にならって以下のように冠循環系の階層的構造 を表す，即ち，各階層における血液を異なる流体相， 心室壁をこれらの流体相と心筋基質による固体相から なる多相混合体とみなして微小循環のモデル化を行う。 また，各階層の血管系における血流に対寸る抵抗を透 過率(permeability), 各階層間の血液流れに対する抵抗を 転送係数(transfer coefficient), 各階層の血管弾性をコン プライアンスとして定義する．さらに心笳圧は心筋基 質の固体相と各階層血液の流体相の非圧縮性を通じて, また心筋内血液容量は混合体における各流体相の体積 率を通じて反映させる. しかし, Huyhge らの定式化で は，構成則を導く際に導入した有効念力の物理的意味 づけが不明確なため, 流体相ひいては混合体の応力に ついて適切な定義がされていないと考えられる。この 点に関しては, 1996 年までの理論的モデル化を主体と した研究 ${ }^{(7,8,10,11)}$, その後の冠循環一の応用 ${ }^{(12,13)}$, さらに 最近では2001 年の骨格筋の灌流(9)への応用においても 改善されていない.これに対し，本研究では混合体理 論に基づき，各種保存則，エントロピーの不等式及び 固体相と流体相の非圧縮仮定より厳密に各相及び混合 体の構成則を導く、これによってより合理的構成則を 導出できることを第 3 章で述べる．以上のモデル化に より，冠循環の血行動態、動脈硬化や血栓などによる 冠循環障害の病態をより合理的に表現することを目指 して，まず上記の階層的多相混合体に基づく冠循環数 理モデルの定式化を行い, 数值解析例を通じて提案し たモデルの有効性について検証を行う。

\section{2. 冠循環混合体モデルの基礎式}

本節ではまず混合体理論の基礎式を導入する．混合 体理論では，各相が同時に同じ空間位置を占めるとし て, 着目する任意の空間微小体積では各相が連続的に 分布し, 各相における質量, 運動量, エネルギー保存 則及ひ熱力学第二法則が成り立つと仮定している. 小 動脈，小静脈より細い血管及び毛細血管がほぼ心筋内 に満遍なく分布しているため, 図3に示すように心筀 基質を固体相, 各階層の血液を異なる流体相とすれば, 心蔵壁に多相混合体の仮定を適用できると考えられる。 混合体微小体積 $d v$ に対する固体相微小体積 $d v^{s}$ 及 び第 $i$ 階層流体相微小体積 $d v^{f^{i}}$ の比を体積率 $\phi^{s}$ 及び $\phi^{f^{i}}$ として 


$$
\phi^{s}=\frac{d v^{s}}{d v}, \quad \phi^{f^{i}}=\frac{d v^{f^{i}}}{d v}
$$

と定義すれば、飽和状態において

$$
\sum \phi^{\alpha}=1 \quad\left(\alpha=s, f^{1}, f^{2},,, f^{n}\right)
$$

の関係を満足する．また，混合体体積における各相の 見かけの質量密度(apparent density) $\rho^{\alpha}$ は実質質量密度 (true density) $\rho_{T}^{\alpha}$ から次のように定義される.

$$
\rho^{\alpha}=\phi^{\alpha} \rho_{T}^{\alpha}
$$

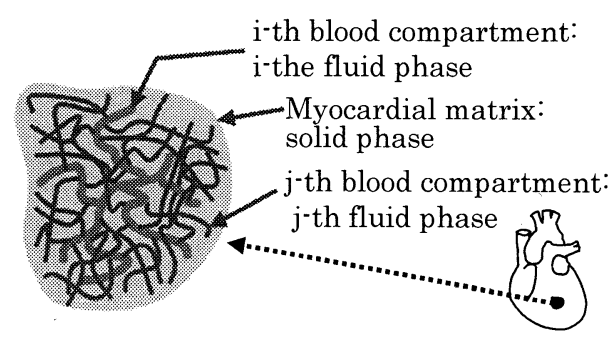

Fig. 3 Mixture model of heart wall

2 - 1 質量保存則 他相との質量交換率を $\xi^{\alpha}$ と して $\alpha$ 相に関する質量保存則は次のように与えられ る.

$$
\frac{\partial \rho^{\alpha}}{\partial t}+\nabla \cdot\left(\rho^{\alpha} v^{\alpha}\right)=\xi^{\alpha}
$$

固体相と流体相の間で化学反応などによる質量交換を 生じない場合は次式が成り立つ。

$$
\xi^{s}=0, \quad \sum_{f_{i}} \xi^{f_{i}}=0
$$

2 -2 運動量保存則 他相との質量交換に伴う 運動量増加率を $\xi^{\alpha} \boldsymbol{v}^{\alpha}$, 他相との相互作用力を $\pi^{\alpha}$ とし て, $\alpha$ 相に関する運動量保存則は次式で与えられる.

$$
\rho^{\alpha} \frac{D^{(\alpha)} \boldsymbol{v}^{\alpha}}{D t}=\nabla \cdot \boldsymbol{\sigma}^{\alpha}+\rho^{\alpha} \boldsymbol{b}^{\alpha}+\boldsymbol{\pi}^{\alpha}
$$

$\boldsymbol{v}^{\alpha}, \boldsymbol{\sigma}^{\alpha}$ 及び $\rho^{\alpha} \boldsymbol{b}^{\alpha}$ はそれぞれ $\alpha$ 相の速度, 応力及び 体積力を表わしている. 各階層の流体相は互いに接続 され，また流体相と固体相間の質量交換はないため, 混合体全体に関しては次の条件が適用される.

$$
\sum_{\alpha} \pi^{\alpha}=0
$$

各相間の質量交換による運動量の変化が無視できると して, 混合体の応力は次式で表すことができ(6)

$$
\boldsymbol{\sigma}=\sum_{\alpha} \boldsymbol{\sigma}^{\alpha}=\boldsymbol{\sigma}^{s}+\sum_{f^{\prime}} \boldsymbol{\sigma}^{f^{i}}
$$

式(7)を考慮して，式(6)を各相について総和をとること により, 混合体の運動方程式が次のように得られる.

$$
\sum_{\alpha} \rho^{\alpha} \frac{D^{(\alpha)} \boldsymbol{v}^{\alpha}}{D t}=\nabla \cdot \boldsymbol{\sigma}+\sum_{\alpha} \rho^{\alpha} \boldsymbol{b}^{\alpha}
$$

$2 \cdot 3$ エネルギ一保存則 内部エネルギーを $\varepsilon^{\alpha}$ ， 運動エネルギ一密度を $\boldsymbol{v}^{\alpha^{2}} / 2$, 他相から受ける作用力 による機械的仕事率を $\boldsymbol{\pi}^{\alpha} \cdot \boldsymbol{v}^{\alpha}$, 他相との内部エネルギ 一密度の交換を $\hat{\varepsilon}^{\alpha}$ として， $\alpha$ 相に関するエネルギ一保 存則は次式によって表される.

$$
\rho^{\alpha} \frac{D^{(\alpha)} \varepsilon^{\alpha}}{D t}=\boldsymbol{\sigma}^{\alpha}: \boldsymbol{L}^{\alpha}-\nabla \cdot \boldsymbol{q}^{\alpha}+r^{\alpha}+\hat{\varepsilon}^{\alpha}
$$

但し， $\boldsymbol{L}^{\alpha}$ は変形速度勾配テンソル， $\boldsymbol{q}^{\alpha}$ 及び $r^{\alpha}$ は混合 体表面からの熱流及び内部熱源密度である。準静的問 題として運動エネルギーを無視し, また熱力学的均一 状態を仮定すれば，混合体全体に対して次の条件が課 される.

$$
\sum_{\alpha}\left(\boldsymbol{\pi}^{\alpha} \cdot \boldsymbol{v}^{\alpha}+\hat{\varepsilon}^{\alpha}\right)=0
$$

$2 \cdot 4$ エントロピー不等式 混合体内温度 $T$ の 分布が均一であると仮定し, 単位質量のエントロピー 密度を $s^{\alpha}$, 他相との質量交換に伴うエントロピーの流 入率を $\xi^{\alpha} s^{\alpha}$ とし, 温度の時間的変化を無視して次式 で定義される Helmholtz 自由エネルギー

$$
\Phi^{\alpha}=\varepsilon^{\alpha}-T s^{\alpha}
$$

を用いると, 混合体全体のエントロピー不等式は

$$
-\sum_{\alpha} \rho^{\alpha} \frac{D^{(\alpha)} \Phi^{\alpha}}{D t}+\sum_{\alpha} \boldsymbol{\sigma}^{\alpha}: \boldsymbol{L}^{\alpha}-\sum_{\alpha} \boldsymbol{\pi}^{\alpha} \cdot \boldsymbol{v}^{\alpha} \geq 0
$$

となる.

\section{$2 \cdot 5$ 非圧縮条件 心筋基質及び血液の非圧縮} 性

$$
\frac{D^{(\alpha)} \rho_{T}^{\alpha}}{D t}=0
$$

を仮定すると次式が得られる.

$$
\frac{\partial \phi^{\alpha}}{\partial t}+\nabla \cdot\left(\phi^{\alpha} v^{\alpha}\right)=\theta^{\alpha}
$$

ここで

$$
\theta^{\alpha}=\xi^{\alpha} / \rho_{T}^{\alpha}
$$

は単位混合体体積における $\alpha$ 相に流入した体積を表 している. 式(15)を各流体相について総和を取り，さ らに式(5)及び飽和条件式(2)を導入することにより次 式が導かれる。

$$
\nabla \cdot \boldsymbol{v}^{s}+\sum_{f^{\prime}} \nabla \cdot \boldsymbol{w}^{f^{\prime}}=0
$$

但し, 


$$
\boldsymbol{w}^{f^{i}}=\phi^{f^{i}}\left(\boldsymbol{v}^{f^{i}}-\boldsymbol{v}^{s}\right)
$$

は流体相の相対流速である. さらに展開すると次式が 得られる.

$$
\sum_{\alpha} \phi^{\alpha} \operatorname{tr} \boldsymbol{L}^{\alpha}+\sum_{f^{i}}\left(\boldsymbol{v}^{f^{i}}-\boldsymbol{v}^{s}\right) \cdot \nabla \phi^{f^{i}}=0
$$

\section{3. 構成則及び空間的・階層的流動則}

本節では，本研究の理論的核心である，階層的多相 混合体冠循環モデルにおける固体相, 流体相の構成則, さらに，空間的に共存する同一階層内の流れ及び同じ 空間位置での階層的流れを支配する流動則の導出を行 ว.

3- 1 エントロピー不等式の展開 非圧縮条件 式(19)を Lagrange 未定乗数 $p$ によりエントロピー不等 式(13)に導人すると, 非圧縮条件を考慮した等価的工 ントロピー不等式が得られる.

$$
\begin{aligned}
& -\sum_{\alpha} \rho^{\alpha} \frac{D^{(\alpha)} \Phi^{\alpha}}{D t}+\sum_{\alpha} \boldsymbol{\sigma}^{\alpha}: \boldsymbol{L}^{\alpha}-\sum_{\alpha} \pi^{\alpha} \cdot \boldsymbol{v}^{\alpha} \\
& +p\left[\sum_{\alpha} \phi^{\alpha} \operatorname{tr} \boldsymbol{L}^{\alpha}+\sum_{f^{i}}\left(\boldsymbol{v}^{f^{i}}-\boldsymbol{v}^{s}\right) \cdot \nabla \phi^{f^{i}}\right] \geq 0(20)
\end{aligned}
$$

任意物理量 $A$ に対し， $\alpha$ または $\beta$ 相を参照した物質時 間微分間の関係は次式として得られる.

$$
\frac{D^{(\alpha)} A}{D t}=\frac{D^{(\beta)} A}{D t}+\left(v^{\alpha}-v^{\beta}\right) \cdot \nabla A
$$

また, 固体相の変形勾配テンソル $\boldsymbol{F}^{s}$ を導入すれば, $J^{s}=\operatorname{det} \boldsymbol{F}^{s}$ は固体相の体積変化率を表すため, 固体相 物質の非圧縮性仮定より変形前後の固体相体積率は次 式で関連付けられる.

$$
\phi_{0}^{s}=J^{s} \phi^{s}
$$

密度の関係式(3), 非圧縮条件式(14)及び式(22)より次式 が得られる。

$$
\rho^{s} \frac{D^{(s)} \Phi^{s}}{D t}=\frac{1}{J^{s}} \frac{D^{(s)} \Phi_{0}^{s}}{D t}
$$

ここで $\Phi_{0}^{s}$ は基準配置での単位混合体体積における固 体相の Helmholtz 自由エネルギーである.

心筋基質はコラーゲン線維などからなる固体相とし てひずみエネルギーを持つほか，各階層の血管もひず みエネルギーを持ち，血管が心笳基質に固着している と仮定すると，血管のひずみエネルギーも心筋変形に 寄与していると考えられる：従って，血管の変形が血 液の体積率によって生じると仮定すると，固体相単位 質量当りの Helmholtz 自由エネルギーの物質時間微分 は次式によって与えられる.

$$
\begin{aligned}
& \rho^{s} \frac{D^{(s)} \Phi^{s}}{D t}=\frac{1}{J^{s}} \frac{D^{(s)} \Phi_{0}^{s}}{D t} \\
& =\frac{1}{J^{s}}\left(\frac{\partial \Phi_{0}^{s}}{\partial C^{s}}: \frac{D^{(s)} C^{s}}{D t}+\sum_{f^{i}} \frac{\partial \Phi_{0}^{s}}{\partial \phi^{f^{i}}} \frac{D^{(s)} \phi^{f^{i}}}{D t}\right)
\end{aligned}
$$

但し, $C^{s}$ は固体相の右 Cauchy-Green 変形テンソルで ある. 式(24)の展開については，まず $\partial \Phi_{0}^{s} / \partial \boldsymbol{C}^{s}$ の対称 性を利用して次式が得られる。

$$
\frac{1}{J^{s}} \frac{\partial \Phi_{0}^{s}}{\partial \boldsymbol{C}^{s}}: \frac{D^{(s)} \boldsymbol{C}^{s}}{D t}=\frac{1}{J^{s}}\left(\boldsymbol{F}^{s} \cdot \frac{\partial \Phi_{0}^{s}}{\partial \boldsymbol{E}^{s}} \cdot \boldsymbol{F}^{s T}\right): \boldsymbol{L}^{s}(25)
$$

次に非圧縮条件式(15)を用いて

$$
\begin{aligned}
& \frac{1}{J^{s}} \sum_{f^{i}} \frac{\partial \Phi_{0}^{s}}{\partial \phi^{f^{i}}} \frac{D^{(s)} \phi^{f^{i}}}{D t} \\
= & \frac{1}{J^{s}} \sum_{f^{i}} \frac{\partial \Phi_{0}^{s}}{\partial \phi^{f^{i}}}\left[\theta^{f^{i}}-\phi^{f^{i}} \operatorname{tr} \boldsymbol{L}^{f^{i}}-\nabla \phi^{f^{i}} \cdot\left(\boldsymbol{v}^{f^{i}}-\boldsymbol{v}^{s}\right)\right](26)
\end{aligned}
$$

が導かれる，一方，流体相に関しては，ひずみエネル ギー，内部粘性及び各相間の拡散による散冕効果が小 さいとし，また流体相の Helmholtz 自由エネルギーの 変化が無視できると仮定すると，式(25)〜(26)を式(20) に代入し，式(7)を利用して次式が得られる。

$$
\begin{aligned}
& {\left[-\frac{1}{J^{s}}\left(\boldsymbol{F}^{s} \cdot \frac{\partial \Phi_{0}^{s}}{\partial \boldsymbol{E}^{s}} \cdot \boldsymbol{F}^{s T}\right)+\boldsymbol{\sigma}^{s}+\phi^{s} p \boldsymbol{I}\right]: \boldsymbol{L}^{s}} \\
& +\sum_{f^{i}}\left[\frac{1}{J^{s}} \frac{\partial \Phi_{0}^{s}}{\partial \phi^{f^{i}}} \phi^{f^{i}} \boldsymbol{I}+\boldsymbol{\sigma}^{f^{i}}+\phi^{f^{i}} p \boldsymbol{I}\right]: \boldsymbol{L}^{f^{i}} \\
& \sum_{f^{i}}\left[\left(\frac{1}{J^{s}} \frac{\partial \Phi_{0}^{s}}{\partial \phi^{f^{i}}}+p\right) \nabla \phi^{f^{i}}-\boldsymbol{\pi}^{f^{i}}\right] \cdot\left(\boldsymbol{v}^{f^{i}}-\boldsymbol{v}^{s}\right) \\
& -\sum_{f^{i}} \frac{1}{J^{s}} \frac{\partial \Phi_{0}^{s}}{\partial \phi^{f^{i}}} \theta^{f^{i}} \geq 0
\end{aligned}
$$

$3 \cdot 2$ 構成則 Coleman 式(27)左辺の固体相及び流体相変形速度勾配テンソル $\boldsymbol{L}^{s}, \boldsymbol{L}^{f^{i}}$ が互いに独立であり，任意の熱力学的過程に 対して不等式(27)が成り立つため，これらの独立変数 の係数がゼロになる必要があるとしている．従って， 固体相の変形による応力を

$$
\boldsymbol{\sigma}_{E}^{s}=\frac{1}{J^{s}}\left(\boldsymbol{F}^{s} \cdot \frac{\partial \Phi_{0}^{s}}{\partial \boldsymbol{E}^{s}} \cdot \boldsymbol{F}^{s T}\right)
$$

と定義し，流体相に対しては， 


$$
\tilde{p}^{f^{\prime}}=\frac{1}{J^{s}} \frac{\partial \Phi_{0}^{s}}{\partial \phi^{f^{i}}}
$$

と定義すれば

$$
\begin{gathered}
\boldsymbol{\sigma}^{s}=-\phi^{s} p \boldsymbol{I}+\boldsymbol{\sigma}_{l:}^{s} \\
\boldsymbol{\sigma}^{f^{i}}=-\phi^{f^{i}} \bar{p}^{f^{i}} \boldsymbol{I}
\end{gathered}
$$

がそれぞれ固体相と流体相の構成則として得られる.

ここでは, Lagrange 未定乗数 $p$ は心筋基質の静水圧に 対応しており, また血液の圧力は

$$
\bar{p}^{f^{i}}=p+\tilde{p}^{f^{i}}
$$

によって与えられる.ささらに式(29)より，血管内外圧 力差を示寸経壁圧 (transmural pressure) $\tilde{p}^{f^{i}}$ は血管によ る Helmholtz 自由エネルギ一，即ち血管弾性コンプラ イアンスに依存することが分かる．混合体の構成則と

しては式(8), (30)〜(32)より次式で与えられる.

$$
\boldsymbol{\sigma}=-\left(\phi^{s} p+\sum_{f^{i}} \phi^{f^{i}} \bar{p}^{f^{i}}\right) \boldsymbol{I}+\boldsymbol{\sigma}_{E}^{s}
$$

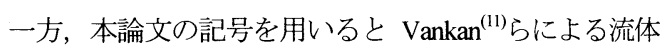
相及び混合体の構成則は次のようになる.

$$
\begin{aligned}
& \boldsymbol{\sigma}^{f^{i}}=\left[\tilde{\psi}^{f^{i}}-\phi^{f^{f}}\left(\tilde{p}^{f^{i}}+p\right)\right] \boldsymbol{I} \\
& \boldsymbol{\sigma}=-p \boldsymbol{I}+\boldsymbol{\sigma}_{E}^{s}
\end{aligned}
$$

式(34)の $\tilde{\psi}^{f^{i}}=\phi^{f^{i}} \Phi^{f^{\prime}}$ は単位混合体体積における流体 相の自由エネルギーとされており，その具体的形式は 与えられていない，また， $p$ は心筋圧力のはずである が, 式(35)の $p$ は混合体の静水圧と解釈され, 両者が 混同されている. 一方, 本研究では, 式(33)右辺の第 1 項目を混合体の静水圧とすれば，各相の体積率及び 各流体相血管のコンプライアンスがそれに寄与してい ることが理解できる.この違いは各流体相の力学的挙 動に大きく影響を及ぼすと考えられる.

3 - 3 空間的 - 階層的流動則 第 $k$ 階層の流体 相に対し, 上位階層からの体積流入率を $\omega^{f^{k-1}}$, 下位階 層への体積流出率を $\omega^{f^{k}}$ とすれば, 総体積流入率 $\theta^{f^{k}}$ は次のようになる.

$$
\theta^{f^{k}}=\omega^{f^{k-1}}-\omega^{f^{k}}\left(k=1, n ; \omega^{f^{0}}=\omega^{f^{0}}=0\right)(36)
$$

これにより次式が得られる.

$$
\sum_{f^{\prime}} \tilde{p}^{f^{i}} \theta^{f^{i}}=\sum_{k=1, n-1} \omega^{f^{k}}\left(\tilde{p}^{f^{k+1}}-\tilde{p}^{f^{k}}\right)
$$

式(30)，(31)及び(37)を式(27)に代入し，さらに流体相応 力式(31)を運動方程式(6)に代入して慣性力と体積力を 無視した結果を用いると式(27)は次のようになる.

$\sum_{f^{i}}-\phi^{f^{i}} \nabla \bar{p}^{f^{i}} \cdot\left(\boldsymbol{v}^{f^{i}}-\boldsymbol{v}^{s}\right)-\sum_{k=1, n-1} \omega^{f^{k}}\left(\tilde{p}^{f^{k+1}}-\tilde{p}^{f^{k}}\right) \geq 0$

上式を満たすため, まずマトリックス定義

$\{\beta\}^{T}=\left\{-\phi^{f^{\prime}} \nabla \bar{p}^{f^{1}}, \ldots,-\phi^{f^{1}} \nabla \bar{p}^{f^{1}}, \ldots,-\phi^{f^{n}} \nabla \bar{p}^{f^{n}}\right.$,

$\left.-\left(\tilde{p}^{f^{2}}-\tilde{p}^{f^{1}}\right), \ldots,-\left(\tilde{p}^{f^{k}}-\tilde{p}^{f^{k-1}}\right), \ldots,-\left(\tilde{p}^{f^{n}}-\tilde{p}^{f^{n-1}}\right)\right\}$

$$
\begin{aligned}
& \{\gamma\}^{T}=\left\{\boldsymbol{v}^{f^{\prime}}-\boldsymbol{v}^{s}, \ldots, \boldsymbol{v}^{f^{k}}-\boldsymbol{v}^{s}, \ldots, \boldsymbol{v}^{f^{n}}-\boldsymbol{v}^{s},\right. \\
& \left.\omega^{f^{\prime}}, \ldots, \omega^{f^{k-1}}, \ldots \omega^{f^{n-1}}\right\}
\end{aligned}
$$

を用いて式(38)を次のように書き直し，

$$
\{\beta\}^{T}\{\gamma\} \geq 0
$$

二つの変数マトリックスの間に一次近似として

$$
\{\beta\}=[k]\{\gamma\}
$$

の線形関係を仮定すると, 係数マトリックス $[k]$ が正 定值であれば

$$
\{\gamma\}^{T}[k]^{T}\{\gamma\} \geq 0
$$

が成り立つ. 即ち不等式(38)を満たすことができる.

各階層間，または空間・階層間の相互作用が無視で きると仮定すれば, 係数マトリックス $[k]$ は対角行列 となり, 次の関係式が導かれる.

$$
\begin{aligned}
& -\phi^{f^{i}} \nabla \bar{p}^{f^{i}}=\boldsymbol{k}^{f^{i}} \cdot\left(\boldsymbol{v}^{f^{i}}-\boldsymbol{v}^{s}\right), i=1, n \\
& \omega^{f^{j}}=-\kappa_{j}\left(\tilde{p}^{f^{j+1}}-\tilde{p}^{f^{j}}\right)
\end{aligned}
$$

あるいは式(44)を書き直すと

$$
\boldsymbol{w}^{f^{i}}=-\boldsymbol{\kappa}^{f^{i}} \cdot \nabla \bar{p}^{f^{i}}
$$

が得られ，式(45)と式(46)はそれぞれ階層間または空間 的流れを支配する流動則となっている。式(45)の $\kappa_{j}$ は 輸送係数(transfer coefficient) と呼ばれ，式(46)は多孔質 体における Darcy 則に相当し, $\boldsymbol{\kappa}^{f^{\prime}}$ は透過係数である.

\section{4. 大変形問題の定式化}

心蔵の収縮・拡張は常に大変形を伴うため, 本節で は変形前の状態を基準配置とする大変形問題の定式化 
を行う.任意のスカラー $p$, ベクトルまたはテンソル $\boldsymbol{a}$ に対して, 変形勾配 $\boldsymbol{F}$ 及び $\boldsymbol{F}$ の行列式 $J$ を用いた Piola 変換

$$
\boldsymbol{A}=J \boldsymbol{F}^{-1} \cdot \boldsymbol{a}
$$

を行うと次式が成立する ${ }^{(15)}$.

$$
\nabla_{0} \cdot \boldsymbol{A}=J \nabla \cdot \boldsymbol{a}, \quad \nabla p=\boldsymbol{F}^{-T} \cdot \nabla_{0} p
$$

ここで $\nabla_{0}$ は参照配置における微分演算子である. 以下 では簡潔のため固体相の変形勾配の添え字 $s$ を省略す る.

まず慣性力と体積力を無視して，混合体の運動方程 式(9)及び構成則(33)より次式が得られる.

$\nabla_{0} \cdot\left[-\left(\phi^{s} p+\sum_{f^{\prime}} \phi^{f^{i}} \bar{p}^{f^{i}}\right) J \boldsymbol{F}^{-1}+J \boldsymbol{F}^{-1} \cdot \boldsymbol{\sigma}_{E}^{s}\right]=\boldsymbol{O}(49)$

次いで Piola 変換及び式(32)を式(46)に適用することに より各流体相における空間的流動則は次のようになる.

$$
\boldsymbol{W}^{f^{i}}=-\boldsymbol{K}^{f^{i}} \cdot \nabla_{0} \bar{p}^{f^{i}}
$$

但し，

$$
\boldsymbol{K}^{f^{i}}=J \boldsymbol{F}^{-1} \cdot \boldsymbol{\kappa}^{f^{i}} \cdot \boldsymbol{F}^{-T}
$$

さらに, Piola変換及び $j=J \nabla \cdot v^{s}$ の関係により, 混合 体全体の非圧縮条件式(17)は次のようになる。

$$
\dot{J}+\sum_{f^{i}} \nabla_{0} \cdot \boldsymbol{W}^{f^{i}}=0
$$

また，各階層流体相の非圧縮条件式(15)を展開し，式 (36), (45)及びPiola変換を適用すると次式が得られる.

$$
\begin{aligned}
& \frac{D^{(s)} J \phi^{f^{k}}}{D t}+\nabla_{0} \cdot \boldsymbol{W}^{f^{k}}=-J \kappa_{k-1}\left(\bar{p}^{f^{k}}-\bar{p}^{f^{k-1}}\right) \\
& +J \kappa_{k}\left(\bar{p}^{f^{k+1}}-\bar{p}^{f^{k}}\right) \quad\left(k=1, n ; \kappa_{0}=\kappa_{n}=0\right)(53)
\end{aligned}
$$

上式は単位混合体体積における第 $k$ 階層血液の体積流 出率 $\nabla_{0} \cdot \boldsymbol{W}^{f^{k}}$ と血液体積率の変化率及び階層間血液 流量の関係を示している. 式(53)を全ての流体相につ いて総和を取り，式(52)からその結果を差引きを用い て相対流速を消去し，さらに時間積分を行うと，結局 式(52)は次のようになる.

$$
J-1-\sum_{f^{i}} J \phi^{f^{i}}+\sum_{f^{i}} \phi_{0}{ }^{f^{i}}=0
$$

冠循環問題では血管の変形能力を表すコンプライア ンスは重要な物性であり, 経壁圧の変化に対する血管 体積の変化率として定義される ${ }^{(16)}$. 式(54)の $J \phi^{f^{i}}=d v^{f^{i}} / d V$ は変形前の混合体体積を基準にした
血液，即ち血管の体積を表しているため，その経壁圧 に対する微分

$$
C^{f^{\prime}}=\frac{\partial J \phi^{f^{\prime}}}{\partial \tilde{p}^{f^{\prime}}}=\frac{1}{d V} \frac{\partial d v^{f^{\prime}}}{\partial \tilde{p}^{f^{\prime}}}
$$

は血管のコンプライアンスとなり，血管剛性の逆数に 相当する.これにより

$$
\frac{D^{(s)} J \phi^{f^{\prime}}}{D t}=C^{f^{\prime}} \frac{D^{(s)} \tilde{p}^{f^{\prime}}}{D t}
$$

の関係が得られる. 式(53)に式(50)及び式(56)を代入す ると次式が得られる.

$$
\begin{aligned}
& C^{f^{k}} \frac{D^{(s)}\left(\bar{p}^{f^{k}}-p\right)}{D t}-\nabla_{0} \cdot\left(\boldsymbol{K}^{f^{k}} \cdot \nabla_{0} \bar{p}^{f^{k}}\right) \\
& =-J \kappa_{k-1}\left(\bar{p}^{f^{k}}-\bar{p}^{f^{k-1}}\right)+J \kappa_{k}\left(\bar{p}^{f^{k+1}}-\bar{p}^{f^{k}}\right) \\
& \left(k=1, n ; \kappa_{0}=\kappa_{n}=0\right)
\end{aligned}
$$

最終的には，式(49)，(54)及び(57)の合計 3 組の支配方 程式があり, 対して固体相変位 $\boldsymbol{u}^{s}$, 心笳圧力 $p$ 及び血 液圧力 $\bar{p}^{f^{k}}$ が独立変数となるため, 固体相構成則, 及 び血管コンプライアンスの関係を与えれば，閉じた方 程式系が得られる。

\section{5. 有限要素定式化}

前節で導かれた混合体運動方程式，非圧縮仮定を導入 した混合体における連続の方程式及び各階層の血液に おける連続の方程式（式(49)，(54)及び(57)）の各式に 重み関数 $\delta \boldsymbol{u}, \delta p$ 及び $\delta \bar{p}^{f^{k}}$ をかけ，部分積分を行う と次の弱形式が導かれる。

$$
\int \delta \boldsymbol{E}:\left[-\left(\phi^{s} p+\sum_{f^{\prime}} \phi^{f^{i}} \bar{p}^{f^{i}}\right) J \boldsymbol{C}^{-1}+\boldsymbol{S}_{E}^{s}\right] d V
$$

$$
=\int \delta \boldsymbol{u} \cdot \boldsymbol{\Pi}^{T} \cdot \boldsymbol{N} d S
$$

$$
\begin{aligned}
& \int \delta p(J-1) d V-\sum_{f^{\prime}} \int \delta p\left(J \phi^{f^{i}}-\phi_{0}^{f^{i}}\right) d V=0(59) \\
& \int \delta \bar{p}^{f^{k}} C^{f^{k}} \frac{D^{(s)}\left(\bar{p}^{f^{k}}-p\right)}{D t} d V-\int \delta \bar{p}^{f^{k}} J \kappa_{k-1} \bar{p}^{f^{k-1}} d V \\
& +\int \delta \bar{p}^{f^{k}}\left(J \kappa_{k-1}+J \kappa_{k}\right) \bar{p}^{f^{k}} d V-\int \delta \bar{p}^{f^{k}} J \kappa_{k} \bar{p}^{f^{k+1}} d V \\
& +\int \nabla_{0} \delta \bar{p}^{f^{k}} \cdot \boldsymbol{K}^{f^{k}} \cdot \nabla_{0} \bar{p}^{f^{k}} d V=-\int \delta \bar{p}^{f^{k}} \boldsymbol{W}^{f^{k}} \cdot N d S \\
& \left(k=1, n ; \kappa_{0}=\kappa_{n}=0\right)
\end{aligned}
$$


ここで, 式(58)及び(60)の右辺に第 1 Piola-Kirchhoff 応 力の定義 $\boldsymbol{\Pi}=J \boldsymbol{F}^{-1} \cdot \boldsymbol{\sigma}$ 及び空間的流動則(50)を用いた. 続いて, ガラーキン法の手順に従い, 重み関数及び独 立変数としての混合体変位 $\boldsymbol{u}$, 心筋圧力 $p$, 各階層血 液圧力 $\bar{p}^{f^{k}}$ に対して形状関数による内挿を行えば，離 散化された支配方程式が得られ，これらに対する微分 により接線マトリックスを導くことができる.

\section{6. 解析例}

図4 に示寸側面拘束(confined)モデルにより，まず応 力緩和問題における 2 相混合体モデルとの比較を行っ た上，文献 ${ }^{(13)}$ による骨格筋血液灌流における物性を参 考に設定した物性值（表 1）により，本研究で提案し たモデルに対する検証を行う。また，流体体積率と経 壁圧の関係としてVankan ら ${ }^{(13)}$ が提案した関係式を導入 する. 透過係数及び輸送係数の空間的分布を一定とし て，3階層の流体相はそれぞれ順に細動脈，毛細血管 及び細静脈を表すものとする. なお有限要素としては, 固体相変位場及び流体相圧力場に対し, 共に 8 節点 6 面体要素を用いてメッシュを作成した.

式(57)左辺の第 1 項目は血液体積率の変化率であり 有限の值を持つため, 血管コンプライアンスが十分大 きければ, 経壁圧の時間微分がゼロに近づき, 経壁圧 が一定になる．また，式(57)右辺の輸送係数は階層間 流れに対寸る抵抗の逆数を表しており，それらが十分 大きい場合は各階層間の圧力差がなくなる. 従って, 血管コンプライアンス及び輸送係数を大きく取り，ま た初期経壁圧をゼロにすれば, 各流体相の圧力は心筋 の静水圧に等しくなり, 全階層の血液が一つの流体相 として機能することになるはずである. 但し， 2 相混 合体モデルと比較する場合は, 式(52)に式(50)を代入し て得られる次式

$$
\dot{J}-\nabla_{0} \cdot\left(\sum_{f^{\prime}} \boldsymbol{K}^{f^{i}} \cdot \nabla_{0} p\right)=0
$$

から分かるように，2相混合体モデルにおける等価透 過係数を $\boldsymbol{K}=\sum \boldsymbol{K}^{f^{i}}$ とする必要がある. 以上の考察 を基に, 図 4 に宗す解析モデル上面に $0.1 \mathrm{~mm}$ の強制変 位を与え，血管のコンプライアンス及び輸送係数を共 に $10^{5}$ に設定して応力緩和解析を行った. その結果を 2 相混合体モデル(17)の解析プログラムによる結果と共 に図 5 に示すが、両者はよく一致している.

次に，心臟収縮時の周囲心筋組織による拘束を近似 するため図 4 の confined モデルを用いて，表 1 に示す
骨格筋血液灌流における物性の参考值に基づき，本研 究で提案するモデルに対する検証を行う. 解析では, モデル上面における細静脈血圧をゼロとし, 図4 に示 す有限要素モデルの上面における細動脈血圧を始めの 0.5 秒で 0 から $13.3 \mathrm{kPa}(100 \mathrm{mmHg})$ となるまで上昇させ, また下向きの垂直荷重についてはやはり 0.5 秒で $14.7 \mathrm{kPa}(110 \mathrm{mmHg})$ となるまで線形的に負荷させた後, 次の 0.5 秒で動脈血圧を $10.6 \mathrm{kPa}(80 \mathrm{mmHg})$ まで減少さ せ，また垂直荷重はゼロまで除荷させる境界条件を設 定した. また, 各流体相体積率と経壁圧の関係として Vankan ら ${ }^{(13)}$ が提案した次式を採用し，

$$
J \phi^{f^{k}}=\phi_{0}^{f^{k}}\left(1+\frac{2}{\pi} \arctan \left(\frac{\bar{p}^{f^{k}}-p-p_{s}}{p_{0}}\right)\right)
$$

血管のコンプライアンスは式(55)に基づき上式の微分 より求めた。

図 6 は解析モデル中段付近の心筋及び各流体相血液 の圧力履歴を示している. 境界条件がゼロと設定され ている細静脈の血圧はほぼゼ口に近い值を保っており, また, 毛細血管の血圧も負荷状況に対応した変動を示 しているが，外部負荷とほぼ一致する心筋の圧力が負 荷の段階では細動脈血流圧力より高いため、細動脈の 経壁圧が負圧となっている. 除荷の段階では心筋圧力 が低下し，やがて細動脈の経壁圧が正圧となる。
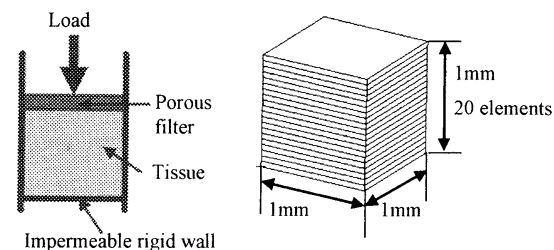

Fig. 4 Confined model and finite element mesh

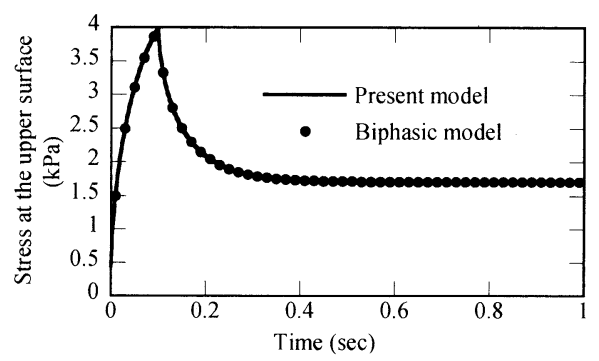

Fig. 5 Comparison of present model with biphasic model for stress relaxation problem 
モデルへの流入を細動脈血流に対しては正，細静脈血 流に対しては負と定義して，これらの流れを心筋圧力 と共に図 7 に示す.負荷により生じる心笳圧力により, 細動脈においては負荷の初期段階ではモデルから流出 する逆流が起こり，その後は動脈血圧の上昇により流 入するようになるが, 流量が比較的に低い. しかし， 除荷が始まると細動脈の流量が急に増え, 負荷段階で の最大值の約 2 倍に達している, 一方, 細静脈血流に 関しては逆流を生じないが，負荷段階において大きく 上昇する流量が，除荷に伴い急に減少する様子が見ら れる。

Table 1 Material properties

\begin{tabular}{|c|c|c|c|}
\hline & Arteriolar & Capillary & Venular \\
\hline $\boldsymbol{k}^{f^{\prime}}$ & 50.0 & 0.5 & 50.0 \\
\hline$\kappa_{j}$ & 2.3 & 2.3 & \\
\hline$p_{0}$ & 0.022 & 0.033 & 0.063 \\
\hline$p_{s}$ & 0.0 & 0.0 & 0.0002 \\
\hline$\phi^{f^{i}}$ & 0.7 & 1.8 & 2.2 \\
\hline $\boldsymbol{k}^{f^{\prime}}:$ Permeability $\left(\mathrm{mm}^{4} / \mathrm{sec}-\mathrm{N}\right)$ \\
$\kappa_{j}:$ Transfer coefficient (mm $\left./ \mathrm{sec}-\mathrm{N}\right)$ \\
$p_{0}, p_{s}:$ Reference pressure (MPa) \\
$\phi^{f^{\prime}}:$ Volume fraction (\%) \\
Young's modulus=0.02MPa ; Poisson's ratio=0.0 \\
\hline
\end{tabular}

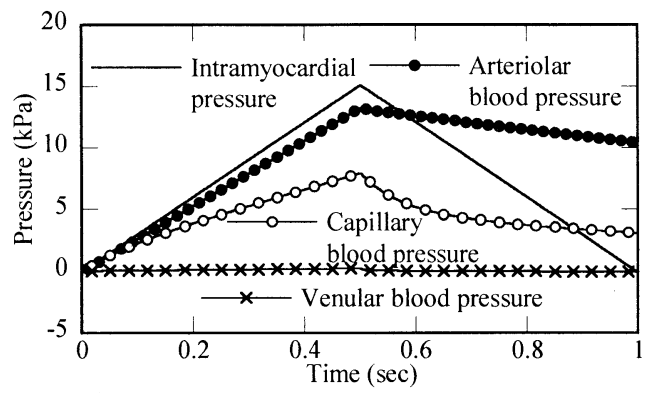

Fig. 6 Temporal variations of intramyocardial, arteriolar blood, capillary blood and venular blood pressures in the middle of FEM model

もちろん本解析例で用いている物性や解析条件は正確 な心臟の状態を反映しているとはいえないが，以上の 結果は、本研究で提案した理論モデルにより冠循環の 特徵として挙げられる収縮期における冠動脈血流の逆 流, 冠動脈における拡張期優位性及び冠静脈における 収縮期優位性を表現できることを示している。なお，
細動脈，毛細血管及び細静脈の体積率の時間変化を示 す図8では, 収縮期の圧縮により減少した各流体相の 体積率が拡張期に再び大きくなり，拡張期優位で入っ てくる動脈血流を貯蔵する機能を再現している.

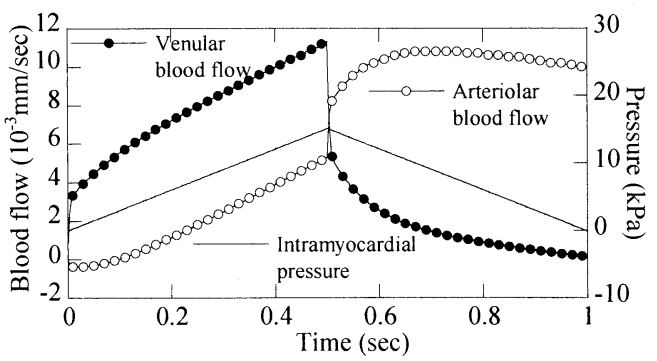

Fig. 7 Temporal variations of the intramyocardial pressure, arteriolar, capillary and venular blood flows in the middle of FEM model

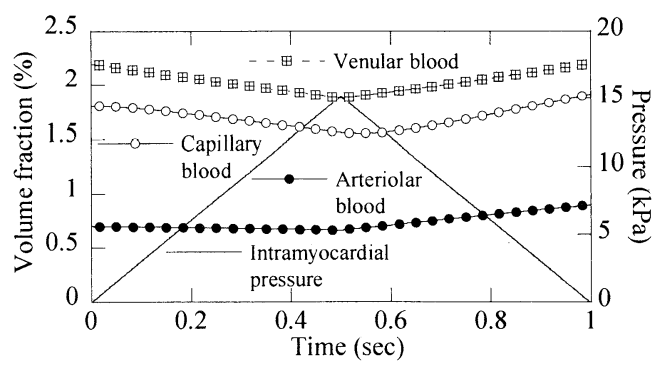

Fig. 8 Temporal variations of the blood volume fractions in the middle of FEM model

\section{7. 結言}

心臟に血液を供給する冠循環は常に心臟の収縮・拡 張に伴って行われるため, 心筋圧力が大きな影響を及 ぼしていることが認識されている，本研究では冠循環 のうちでも微小循環に対し, 先行研究を踏まえて, 冠 循環系を組織学的形態及び生理学的機能に基づく離散 的階層に区分し, 各階層における血液を異なる流体相， 心室壁をこれらの流体相と心筋基質による固体相から なる多相混合体として定式化を行った，さらに新たな 試みとして混合体理論に基づき，流体相及び混合体に 関する合理的な構成則を導いた。これにより心臓の拍 動と冠循環の力学的連成を扱うことのできる混合体数 理モデルを構筑した．また，単純化した数值解析例を 通じて提案した理論モデルの妥当性について検証した。 すなわち、冠循環における冠動脈血流の拡張期優位性、 冠静脈血流の収縮期優位性、拡張期におけるキャパシ タンス効果などの基本的特徵を再現できることを示し 
た。今後の課題としては，冠循環血管系の形態や微小 循環における血行力学に基づくパラメータの推定及び 実験計測による物性の取得, さらに臨床データによる 本提案モデルの検証及び改善が挙げられる.

\section{謝辞}

本研究は, 文部科学省科学研究費補助金（基盤研究 (B)課題番号 18360054）の助成を受けて実施された. ま た，有益な討論をいただいた鷲尾巧氏（科学技術振興 機構）、岡田純一氏（東京大学）に謝意を表する.

\section{文献}

(1) Westerhof, N., Boer, C., Lamberts, R.R. and Sipkema, P., Cross-talk between cardiac muscle and coronary vasculature. Physiological Reviews, Vol.86, No.4 (2006), pp.1263-1308.

(2) Matsumoto, T. and Kajiya, F., Coronary microcirculation: Physiology and mechanics. Fluid Dynamics Research, Vol.37, No.1-2 (2005), pp.60-81.

(3) Smith, N.P. and Kassab, G.S., Analysis of coronary blood flow interaction with myocardial mechanics based on anatomical models. Philosophical Transactions of the Royal Society of London Series a-Mathematical Physical and Engineering Sciences, Vol.359, No.1783 (2001), pp.1251-1262.

(4) Kassab, G.S., Rider, C.A., Tang, N.J. and Fung, Y.C.B., Morphometry of Pig Coronary Arterial Trees. American Journal of Physiology, Vol.265, No.1 (1993), pp.H350-H365.

(5) Truesdell, C., Toupin, R., The Classical Field Theories, (1960, Springer.

(6) Ateshian, G.A., On the theory of reactive mixtures for modeling biological growth. Biomechanics and Modeling in Mechanobiology, Vol.6, No.6 (2007), pp.423-445.

(7) Huyghe, J.M. and Vancampen, D.H., Finite Deformation-Theory of Hierarchically Arranged Porous Solids .1. Balance of Mass and Momentum. International Journal of Engineering Science, Vol.33, No.13 (1995), pp.1861-1871.

(8) Huyghe, J.M. and Vancampen, D.H., Finite Deformation-Theory of Hierarchically Arranged Porous Solids .2. Constitutive Behavior. International Journal of Engineering Science, Vol.33, No.13 (1995), pp.1873-1886.

(9) van Donkelaar, C.C., Huyghe, J.M., Vankan, W.J. and Drost, M.R., Spatial interaction between tissue pressure and skeletal muscle perfusion during contraction. Journal of Biomechanics, Vol.34, No.5 (2001), pp.631-637.

(10) Vankan, W.J., Huyghe, J.M., Drost, M.R., Janssen, J.D. and Huson, A., A finite element mixture model for hierarchical porous media. International Journal for Numerical Methods in Engineering, Vol.40, No.2 (1997), pp.193-210.

(11) Vankan, W.J., Huyghe, J.M., Janssen, J.D. and Huson, A., Poroelasticity of saturated solids with an application to blood perfusion. International Journal of Engineering Science, Vol.34, No.9 (1996), pp.1019-1031.

(12) Vankan, W.J., Huyghe, J.M., Slaaf, D.W., Van Donkelaar, C.C., Drost, M.R., Janssen, J.D. and Huson, A., Finite-element simulation of blood perfusion in muscle tissue during compression and sustained contraction. American Journal of Physiology-Heart and Circulatory Physiology, Vol.42, No.3 (1997), pp.H1587-H1594.

(13) Vankan, W.J., Huyghe, J.M., van Donkelaar, C.C., Drost, M.R., Janssen, J.D. and Huson, A., Mechanical blood-tissue interaction in contracting muscles: a model study. Journal of Biomechanics, Vol.31, No.5 (1998), pp.401-409.

(14) Coleman, B.D. and Noll, W., The Thermodynamics of Elastic Materials with Heat Conduction and Viscosity. Archive for Rational Mechanics and Analysis, Vol.13, No.3 (1963), pp.167-178.

(15) Marsden, J. and Hughes, T.J.R., Mathematical Foundations of Elasticity, (1983), 7, Dover Publications.

(16) Bruinsma, P., Arts, T., Dankelman, J. and Spaan, J.A.E., Model of the Coronary Circulation Based on Pressure-Dependence of Coronary Resistance and Compliance. Basic Research in Cardiology, Vol.83, No.5 (1988), pp.510-524.

(17) Xian Chen, Y.C., Toshiaki Hisada, A Study on Mechanical Model of Soft Tissues by Nonlinear Finite Element Analysis Based on Biphasic Theory. Transactions of the Japan Society of Mechanical Engineers, Series A, Vol.70, No.697 (2004), pp.1208-1215. 